\title{
Kommentar
}

\section{Et virus på fremmarsj}

Denne kasuistikken demonstrerer en god og systematisk tilnærming til en pasient med progredierende nevrologiske utfall. Klinisk undersøkelse viste hjernenerveutfall og etter hvert utfall fra perifere motoriske og sensoriske nerver og fra sentralnervesystemet. Høyt celletall og proteinnivå i spinalvæsken tydet på meningeal inflammasjon, og funn ved $M R$ og nevrografi tydet på affeksjon av nerverøtter $\mathrm{i}$ hjernestamme og spinalt. Til sammen passet dette med arbeidsdiagnosen meningoencefaloradikulitt, og videre utredning og behandling kunne rettes mot dette.

Det er ofte vanskelig å skille mellom autoimmun og infeksiøs etiologi ved meningoencefaloradikulitt. Ettersom dette er en potensielt livstruende tilstand, må mulige årsaker behandles parallelt med utredningen. Denne pasienten ble behandlet for mulig Guillain-Barrés syndrom, nevroborreliose, mykoplasma og herpesencefalitt før en entydig antistoffprofil ga diagnosen skogflåttencefalitt (tickborne encephalitis, TBE).

Skogflåttencefalitt er en infeksjon i sentralnervesystemet med økende forekomst i Europa (1). Ifølge Folkehelseinstituttet har insidensen i Norge økt fra totalt 14 tilfeller i perioden 1998-2005 til 65 tilfeller i perioden 2006-11 (2). Sykdommen har ofte et bifasisk forløp med først en viremisk fase dominert av allmennsymptomer. I fase 2 ses ofte meningoencefalitt med eller uten myelitt og affeksjon av motoriske forhornsceller (1). Sykdommens alvorlighetsgrad øker vanligvis med pasientens alder. Diagnosen baseres på PCR-undersøkelse av serum i viremisk fase eller funn av antistoffer i serum og moderat forhøyet celletall i spinalvæsken i fase 2 (1). Det er kjent at infeksjon kan utløse en autoimmun inflammasjon. I dette tilfellet kan mye tyde på at pasienten både hadde skogflåttencefalitt og GuillainBarrés syndrom.

Guillain-Barrés syndrom er en autoimmun tilstand som kan ha flere kliniske presentasjonsformer, men de forskjellige variantene glir ofte over i hverandre. Det vanligste kliniske bildet domineres av symmetriske lammelser i ekstremitetene, med sensoriske symptomer i hender og føtter, svake/utslukkede senereflekser og noen ganger lammelser $i$ hjernenerver og pustemuskler. En sjelden variant er Miller-Fishers syndrom, som kjennetegnes av øyemuskellammelser med dobbeltsyn, ptose og eventuelt mydriasis pga. autonom affeksjon samt ustøhet/klossethet som følge av sensorisk ataksi. En enda sjeldnere variant er Bickerstaffs hjernestammeencefalitt som kjennetegnes av bevissthetspåvirkning, hyperrefleksi og/eller plantarinversjon (3). De to siste formene er i minst $80 \%$ av tilfellene assosiert med anti-GQ1b-antistoffer i serum (4). Høyt proteinnivå i spinalvæsken er typisk ved Guillain-Barrés syndrom. Pleocytose er uvanlig, men utelukker ikke diagnosen (5). Pasienten ble bedre under oppholdet på universitetssykehus, men i denne tiden ble hun også behandlet med intravenøs immunglobulin, og det kan ikke utelukkes at det bidro til bedring. Selv om det kliniske og laboratoriemessige bildet ikke var helt klassisk, kan det tenkes at dette er det første rapporterte tilfellet av Guillain-Barrés syndrom utløst av skogflåttencefalitt. En slik diagnostisk differensiering er mest av akademisk interesse og endrer ikke noe for pasienten nå $i$ ettertid.

Av denne pasienthistorien kan vi lære at klinisk nevrologisk undersøkelse er viktig, at en arbeidsdiagnose er nyttig, at infeksjon kan utløse autoimmune tilstander og at me- ningoencefalitt er en tilstand med mange mulige årsaker som bør behandles parallelt med utredningen.

\section{Unn Ljøstad}

unn.ljostad@sshf.no

Åse Mygland

Nevrologisk avdeling

Sørlandet Sykehus Kristiansand

Unn Ljøstad (f. 1962) er overlege og spesialist i nevrologi.

Forfatter har fylt ut ICMJE-skjemaet og oppgir ingen interessekonflikter.

Åse Mygland (f. 1958) er overlege og spesialist i nevrologi.

Forfatter har fylt ut ICMJE-skjemaet og oppgir ingen interessekonflikter.

Litteratur

1. Lindquist $L$, Vapalahti 0 . Tick-borne encephalitis Lancet 2008; 371: 1861-71.

2. Folkehelseinstituttet. Smittevernboka. Skogflåttencefalitt (TBE-virusinfeksjoner)

www. fhi.no/eway/default.aspx?pid=233\&trg= MainLeft_6039\&MainArea_5661=6039:0:15,5078:1 $0: 0: 0: 0 \&$ MainLeft_6039=6041:82867:1:6043:107:0:0 (11.1. 2013).

3. Shahrizaila N, Yuki N. Bickerstaff brainstem encephalitis and Fisher syndrome: anti-GQ1b antibody syndrome. J Neurol Neurosurg Psychiatry 2012; e-publisert 15.9.2012.

4. Arányi Z, Kovács T, Sipos I et al. Miller Fisher syndrome: brief overview and update with a focus on electrophysiological findings. Eur J Neurol 2012; 19: 15-20, e1-3.

5. Odaka M, Yuki N, Yamada M et al. Bickerstaff's brainstem encephalitis: clinical features of 62 cases and a subgroup associated with GuillainBarré syndrome. Brain 2003; 126: 2279-90.

Mottatt 26.12. 2012 og godkjent 15.1. 2013. Medisinsk redaktør Merete Kile Holtermann. 